UNITED STATES DEPARTMENT OF THE INTERIOR

J. A. Krug, Secretary

GEOLOGICAL SURVKY

W. E. Wrather, Director

- Bulletin 947-B

\title{
MOLYBDENITE INVESTIGATIONS IN SOUTHEASTERN ALASKA
}

BY

W. S. TWENHOFEL, G. D. ROBINSON, AND H. R. GAULT

Mineral resources of Alaska, 1943 and 1944

(Pages 7-38)

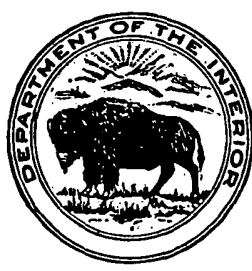

UNITED STATES

GOVERNMENT PRINTING OFFICE

WASHINGTON : 1946 



\section{CONTENTS}

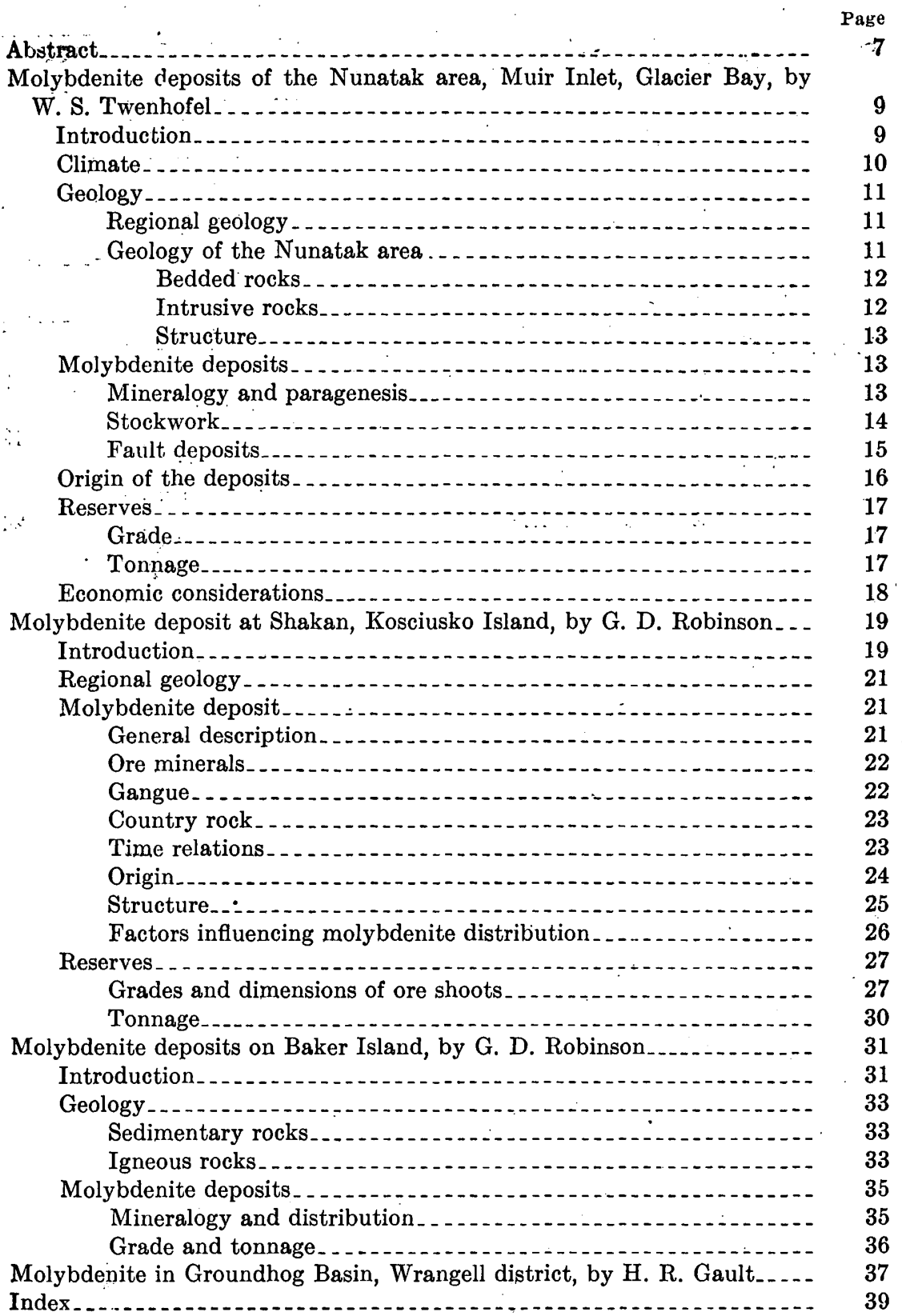




\section{ILLUSTRATIONS}

Plate 1. Geologic sketch map of head of Muir Inlet, Glacier Bay, southeastern Alaska._._._._.

2. Geologic map of Nunatak area, Muir Inlet, Glacier Bay,

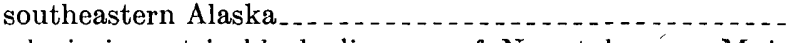

3. Geologic isometric block diagram of Nunatak area, Muir Inlet, Glacier Bay, southeastern Alaska.

In pocket In pocket In pocket

4. Geology and tòpography of Shakan molybdenite deposit, Kosciusko Island, southeastern Alaska.................

5. Map of adit, Shakan molybdenite deposit, Kosciusko Island, southeastern Alaska. . . . . . . . . . . . . . . . .

6. Sample locations and analyses, Shakan molybdenite deposit, Kosciusko Island, southeastern Alaska...............

7. Geologic map of east-central Baker Island, southeastern Alaska . . . . . . . . . . . . . . . . . . . . . . . . . . . . . .

8. Geology of molybdenite deposits, Baker Island, southeastern Alaska

In pocket In pocket In pocket In pocket In pocket

Figure 1. Index map of southeastern Alaska showing the location of molybdenite deposits investigated in 1942 and 1943...-

2. Geologic reconnaissance map of vicinity of Shakan molybdenite deposit, Kosciusko Island, southeastern Alaska.-

3. Diagram showing probable sequence of mineralization, Shakan molybdenite deposit, Kosciusko Island, south.

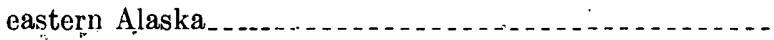




\title{
MOLYBDENITE INVESTIGATIONS IN SOUTHEASTERN ALASKA
}

\author{
By W. S. Twenhofer, G. D. Robinson, and H. R. Gault
}

\begin{abstract}
Four molybdenite deposits in southeastern Alaska were examined by the Geological Survey in 1942 and 1943. The deposits are in the Nunatak area, near the head of Muir Inlet, Glacier Bay; near Shakan, Kosciusko Island; on Baker Island; and in Groundhog Basin, on the mainland east of Wrangell.

In the Nunatak area the bedrock includes tightly folded Paleozoic hornfels and limestone, intruded by a small body of quartz monzonite porphyry, which is surrounded by myriad quartz veinlets. Among the nonmetallic minerals are feldspar, hornblende, diopside, and clinozoisite. The metallic minerals include molybdenite, pyrite, magnetite, and chalcopyrite, of which all but molybdenite are inconspicuous. Two types of molybdenum deposits are recognized. The stockwork type includes the middle part of the zone of quartz veinlets surrounding the intrusive core; it crops out over an area of about 2,170,000 square feet and probably extends many hundred feet below the surface. The fault-zone type is similar, but the rock within it contains many open fractures. The Nunatak fault deposit, the largest of that type, crops out over a length of 2,000 feet, has a known vertical range of about 500 feet, and averages about 9 feet in width. All the molybdenite deposits of the Nunatak area are of low grade. The $\mathbf{1 7 7}$ chip, drill, and channel samples collected by the United States Bureau of Mines from the part of the stockwork mapped as containing conspicuous molybdenite contain from 0.02 to 0.21 percent of molybdenum, with an average of about 0.075 percent. The 56 samples collected by the Bureau of Mines from the part mapped as containing inconspicuous molybdenite contain from 0.02 to 0.11 percent of molybdenum, with an average of 0.048 percent. The samples from the Nunatak fault deposit contain from 0.04 to 0.34 percent of molybdenum, with an average of about 0.102 percent. Assuming that the fault deposit extends to an average depth of 300 feet and the stockwork to an average depth of 500 feet, it is estimated that the Nunatak fault deposit contains about 500,000 tons of indicated molybdenite-bearing rock, of which 280,000 tons contain conspicuous molybdenite, and that the stockwork contains more than $100,000,000$ tons, of which about $8,500,000$ tons contain conspicuous molybdenite.

The molybdenite deposits near Shakan, Kosciusko Island, are in a narrow, lowdipping fault zone and constitute a composite vein in hornblende diorite. Breccia blocks of hornblende diorite are the principal vein filling. The blocks are commonly separated and locally replaced along the margins by bands and small irregular masses of granite pegmatite, lamprophyre, aplite, quartz, quartz-adularia, calcite, zeolites, and iron, copper, and zinc sulfides, in addition to molybdenite. The introduced vein materials appear to have been deposited over a considerable range of temperature but at relatively low pressure. Molybdenite was deposited
\end{abstract}


near the end of the mineralization sequence. Inconclusive evidence indicates that the distribution of molybdenite was probably controlled principally by openings developed in the more steeply dipping parts of the fault zone as a consequence of small-scale normal faulting. Surface and underground workings expose one ore shoot that is estimated to contain between 10,000 and 20,000 tons of measured and indicated ore containing about 1.5 percent of $\mathrm{MoS}_{2}$. A few tens of thousands of tons of additional ore may be inferred in extensions of the known ore shoot and in shoots not now exposed.

The east-central part of Baker Island is underlain by quartz diorite intrusive into slightly recrystallized Devonian(?) argillite and quartzite. The quartz diorite, originally a rather uniform ferromagnesian-poor rock, has been variably brecciated and universally but unequally silicified. The intensity of silicification, although ranging widely within short distances, in general increases toward the northeast. The intensity of brecciation and of silicification are related to the degree of development of joints striking about $\mathrm{N}$. $65^{\circ} \mathrm{W}$. and dipping $70^{\circ}-75^{\circ} \mathrm{S}$. Joints of other prominent sets strike about $\mathrm{N}$. $15^{\circ} \mathrm{W}$., N. $10^{\circ} \mathrm{E}$., and N. $85^{\circ} \mathrm{W}$., and dip very steeply. Many gray or bluish glassy quartz veinlets, mostly occupying the $\mathrm{N} .65^{\circ} \mathrm{W}$. joints, cut the silicified quartz diorite. In most places the veinlets are quantitatively insignificant, but in the small area containing the largest molybdenite deposits they form a reticulating network that comprises from 10 to 50 percent of the rock volume. Molybdenite commonly occurs in small paper-thin patches along the margins of quartz veinlets and in fractures cutting the veinlets. Associated with molybdenite are small amounts of pyrite, arsenopyrite, and pyrrhotite (?). The only noteworthy deposits are on the east coast about 1 mile south of the entrance to Port San Antonio, where molybdenite is exposed in relative abundance for about 700 feet along the beach and in most of the outcrops 400 to 600 feet back of the shore, with an exposed vertical range of about 200 feet. The average molybdenite content of the rocks within this area from the surface to a depth of about 150 feet below sea level is believed to be less than 0.1 percent by weight and probably less than 0.05 percent. Because of their extremely low grade, further development of the Baker Island molybdenite deposits does not appear warranted at present.

In Groundhog Basin, Wrangell district, a northwestward-trending granite sill at least 1,000 feet wide and perhaps several miles long contains sparse molybdenite near its south end. The molybdenite is irregularly distributed as fracture fillings. and in quartz veinlets. 


\title{
MOLYBDENITE DEPOSITS OF THE NUNATAK AREA, MUIR INLET, GLACIER BAY
}

\author{
By W. S. TweNHOFEL
}

\section{INTRGDUCTION}

Muir Inlet is a large fiord that extends northward from the larger and more complex Glacier Bay fiord, a tributary to Icy Strait. . (See fig. 1.) The Glacier Bay district is characterized by huge glaciers

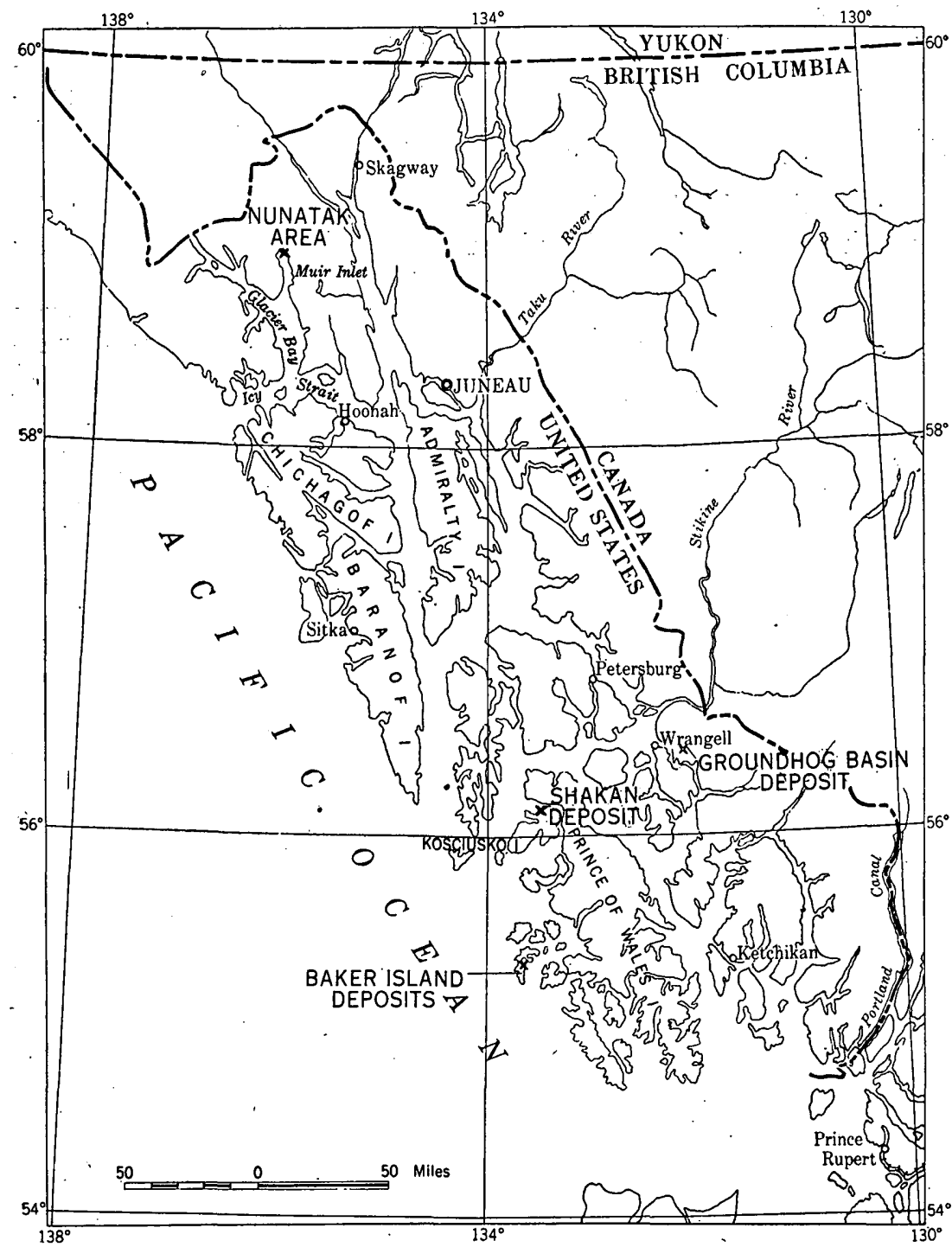

Figdre 1.-Index map of southeastern Alaska, showing the location of molybdenite deposits investigated in 1942-43. 
and mountains. The mountains are part of the Coast Range and St. Elias Range, both very rugged, high ranges, parts of which, in the Glacier Bay district, rise abruptly from sea level to altitudes of 10,000 feet or higher.

The molybdenite deposits are in a small mountain on the east side of Muir Inlet near its head and about $1 \frac{1}{2}$ miles south of the front of the Muir Glacier in 1942. (See pl. 1.) Because the small mountain was until very recently a nunatak in the midst of the glacial ice it will be referred to in this report as the Nunatak, and the general area of the deposit will be referred to as the Nunatak area.

The Nunatak area may best be reached by motor launch from Juneau, about 120 miles by water to the southeast. The nearest town is Hoonah, an Indian village about 65 miles to the south. The numerous icebergs that are frequently near the head of Muir Inlet make its waters dangerous for seaplanes and somewhat hazardous for small boats. ${ }^{1}$ Muir Inlet is said to freeze over occasionally, making the Nunatak area especially difficult of access for short periods during winter.

Until 6 or 7 years ago much of the molybdenite deposit was buried beneath the Muir and McBride Glaciers, and even today the Nunatak is bounded on the east and north by a large mass of stagnant ice. As the retreat of the glaciers has recently exposed most of the Muir Inlet area and as there are very few shrubs and other plants the exposures, except for some morainal cover, are excellent.

In 1942 the Geological Survey party was in the Glacier Bay district from June 13 to.September 15, and except for about 3 weeks the party was engaged in mapping the geology and molybdenite deposits of the Nunatak area. The writer was assisted by David M. Hopkins, geologist, during most of August and the early part of September, and by Ralph W. Mielke who served as camp hand during the last week of June and all of July and August. J. C. Reed visited the party many times and gave freely of $\cdot$ his advice and time both in the field and in the office.

During August and the early part of September a program for testing the molybdenite deposits was conducted by a Bureau of Mines party under the direction of Mr. G. A. Apell and Mr. A. W. Tolonen. While the men from the Bureau of Mines were at the Nunatak the Geological Survey party boarded with them and received from them many other helpful courtesies.

\section{CLIMATE}

Data concerning the climate of the Glacier Bay district are meager. The only weather observations known to the writer are the amateur records kept by the Survey party during the summer of 1942 and the records obtained by Reid ${ }^{2}$ in the summer of 1890 . Reid's observations

${ }^{1}$ U. S. Coast and Geodetic Survey Chart 8306 is used for navigation in this area.

3 Keid, H. F., Studies of Muir Glacier, Alaska : Nat. Geog. Mag.. vol. 4, pp. 80-81, 1892. 
show that the mean temperature for July and August was slightly more than $45^{\circ}$, about $10^{\circ}$ or $11^{\circ}$ colder than the mean temperature at Juneau during the same months. Reid's record of minimum temperature for July was $35.4^{\circ}$ and for August $37.2^{\circ}$. A total of 3.06 inches of rain fell during July 1890 and 4.88 inches during August 1890.

The Survey party's record shows that a total of 17.2 inches of rain fell during a period of 86 days. The wettest month was September, in which 5.25 inches of rain fell during the first 15 days. There were 26 clear or partly cloudy days, 26 rainy days, and 34 cloudy days with no rain. There were no strong winds; usually the weather was very quiet. Temperature readings were taken early each morning and after supper each night so that the readings necessarily are much closer to the minimum than to the maximum temperature. The average of these readings was about $39^{\circ} \mathrm{F}$. On many nights the temperature dropped close to freezing, but the only freezing temperatures recorded were on the night of September 14.

\section{GEOLOGY}

\section{REGIONAL GEOLOGY}

Numerous expeditions have visited Glacier Bay and Muir Inlet, but most of them were principally concerned with the glacial and botanical phenomena that are so well displayed there. The most comprehensive geologic report of the Glacier Bay district is by the Wrights. ${ }^{3}$

Glacier Bay lies within the northern extension of the mountains of the Alexander Archipelago and the Coast Range as well as within the southern extension of the St. Elias Range. From the small amount of data available it appears that Paleozoic calcareous shales and limestones are the predominant rocks of the Glacier Bay district. Rocks of a similar type are found on the northeast half of Chichagof Island. The sediments of the Glacier Bay district are believed to be part of the Chichagof-Glacier Bay anticlinorium. ${ }^{4}$ Metamorphic equivalents of these rocks occur near the numerous granitic intrusives in this region. Most of the beds are tilted at high angles and generally trend northwestward.

\section{GEOLOGY OF THE NUNATAK AREA}

Reed ${ }^{5}$ in 1936 climbed the Nunatak but did not recognize any molybdenite because the ice of the Muir and McBride Glaciers then covered most of the molybdenite showings now exposed.

\footnotetext{
${ }^{8}$ Wright, F. E., and Wright, C. W., The Glacier Bay National Monument in southeastern Alaska, its glaciers and geology, unpublished manuscript in files of the U. S. Geol. Survey.

- Buddington, A. F., and Chapin, Theodore, Geology and mineral deposits of southeastern Alaska : U. S. Geol. Survey Bull. 800, p. 315, 1929.

' Reed, J. C., Some mineral deposits of Glacier Bay and vicinity, Alaska: Econ. Geol., vol. 33 , No. 1, pp. 56-57, 1938.
}

$689318-46-2$ 
In the summer of 1941. a Geological Survey party under the direction of J. C. Reed ${ }^{6}$ discovered the molybdenite deposit. At that time no evidence of claims was seen. Subsequently, however, the Geological Survey was informed that John Johnson, Tom Smith, George Comstock, Carl Vevelstad, and S. H. P. Vevelstad had staked some of the deposits in 1941 prior to Reed's visit and some of them in August 1941 after Reed's visit. As of 1942 the claim owners had done no development work. In 1941 Reed was at the Nunatak for only 2 days, and time did not permit him to determine more than the broader characteristics of the molybdenite deposits.

The bedrocks of the Nùnatak area include a metamorphosed sedimentäry sequence of tightly folded Paleozoic (possibly Devonian) hornfels with some shale and limestone. (See pls. 2 and 3.) The earliest intrusions into the stratified rocks are a group of dark altered dikes and sills not shown on pl. 2. The hornfels was intruded by a small body of quartz monzonite porphyry probably early in Cretaceous time after the folding of the bedded rocks.

Around the intrusive, and developed by it, is a contact aureole characterized by abundant diopside in the hornfels. The diopside imparts a dark color to the normally light-colored hornfels. The contact aureole and the three recognized hornfels units (see pl. 2) are cut by myriad quartz veinlets. The quartz veinlets are increasingly abundant toward the intrusive mass. Near its periphery they coalesce and leave only faint remnants of the original rock. In places the outer part of the intrusive is almost completely silicified.

Bedded rocks. - The oldest rock unit exposed in the Nunatak area consists of dark blue, very fine-grained, thin-bedded limestone and a few shale beds. The limestone is estimated to contain about 50 percent calcite and about 50 percent quartz and feldspar, with a little carbonaceous material. Conformably overlying the limestone is a thick section of hornfels, which has been differentiated on the map into three units. All three units are fine-grained, hard, and dense, and they closely resemble chert. The hornfels consists principally of orthoclase and clinozoisite, with varying amounts of oligoclase and diopside. The hornfels ranges in color from light yellow green to salmon pink to chocolate brown.

The lower hornfels unit is characteristically thin-bedded and has a few limy beds. The middle unit is characteristically thin-bedded and contains many beds of coarse-grained, salmon-pink clinozoisite. The upper hornfels unit is thick-bedded.

Intrusive rocks.-The oldest intrusive rocks. are greatly altered and deformed basaltic dikes and sills and are not shown on plate 2. In-

\footnotetext{
${ }^{6}$ Smith, P. S., Occurrences of molybdenum minerals in Alaska: U. S. Geol. Survey Bull. 926-C, pp.. 178-180, 1942.
} 
truded into the bedded rocks and altered dikes and sills is a small stock of quartz monzonite porphyry. In places, especially near its outer borders, it is largely silicified. The phenocrysts are large, euhedral, zoned crystals ranging from oligoclase to sodic andesine. The ground mass is finely crystalline quartz and orthoclase with some oligoclase. From 1 to 2 percent of fine-grained biotite and magnetite are also present. After the intrusion of the quartz -monzonite porphyry the Nunatak area was intruded by hundreds of large and small dikes. These dikes are dominantly hornblende andesite porphyry with some dacite porphyry. They are characterized by a predominance of lightcolored minerals. The phenocrysts are generally euhedral, zoned plagioclase crystals, which range from oligoclase to andesine. The hornblende phenocrysts are commonly twinned and are less numerous than the feldspar phenocrysts. Two of the dikes contain phenocrysts of quartz and plagioclase and hence are properly called dacite porphyry.

The ground mass of the dikes consists of tiny laths of sodic plagioclase intercrystallized with some hornblende. However, some of the dikes have a trachytic texture, and the dacites have a spherulitic ground mass. Accessory minerals include pyrite, magnetite, and sphene. The dike rocks appear fresh, although in a few the hornblende has been altered to chlorite.

Structure.-The general trend of the bedded rocks is about N. $5^{\circ} \mathrm{W}$, but at most places, because of minor plications, the rocks strike about N. $30^{\circ}$ E. Near the stock the bedding has been obscured. Steeply dipping, closely spaced joints cross all the bedrocks. The majority of these strike about N. $65^{\circ} \mathrm{W}$. The numerous quartz veinlets for the most part are in these joints. Many faults strike northeastward and dip steeply southeastward. A few of the faults are zones as much as 75 feet wide. The most recent dikes are approximately vertical and trend northeastward. Fault movements both preceded and followed the formation of the quartz veinlets and the intrusion of the dikes.

MOLYBDENITE DEPOSITS

\section{MINERALOGY AND PARAGENESIS}

The mineralogy of the deposits is simple. The minerals introduced during the mineralization that brought in the molybdenite are pyrite, chalcopyrite, magnetite, quartz, orthoclase, oligoclase, hornblende, clinozoisite, diopside, and molybdenite.

Molybdenite $\left(\mathrm{MoS}_{2}\right)$, the only molybdenum mineral in the deposits, is the most conspicuous metallic mineral and in many of the veins is the only metallic mineral. It is unequally distributed principally as films and thin plates along and parallel to the margins of many of the quartz veinlets. Some molybdenite forms very thin seams without 
quartz and, here and there, sparsely distributed aggregates of platelike crystals lie within quartz veinlets. No molybdenite was observed in the hornfels fragments between the veinlets. Molybdenite is easily recognized by its softness and its typical metallic blue-black luster.

Pyrite is widely distributed throughout the mineralized zone, both in the quartz veinlets and in the hornfels between the veinlets. Because it is fine-grained and disseminated it is not as conspicuous as the molybdenite, although heavy mineral analyses show that pyrite is about as abundant as molybdenite. Some of the pyrite at the surface has been altered to limonite that now stains much of the mineralized area.

Chalcopyrite occurs in much the same manner as pyrite but in smaller. amounts.

Quartz in veins and as a replacement mineral is the most abundant mineral in the deposits. The veinlets of the mineralized area are made up almost entirely of dense quartz.

Orthoclase and oligoclase are present in minor amounts as anhedral crystals intergrown with quartz in the veinlets.

Coarse-grained hornblende is widely but irregularly distributed throughout the stockwork. It forms veinlets and occurs along the margins of some quartz veinlets.

Clinozoisite is present as a replacement mineral in the hornfels and as a vein mineral. Much of the replacement clinozoisite is salmon pink, whereas the vein clinozoisite is light green.

Diopside is present as a replacement mineral and as a vein mineral. It occurs along the margins of the quartz veins and as irregular masses within the hornfels. It was not recognized in the field, as it is invariably masked by the more abundant hornblende.

The general order of deposition of the minerals associated with vein mineralization seems to have been amphibole and diopside, quartz and feldspar, molybdenite, pyrite and chalcopyrite, and finally clinozoisite.

No quicksilver minerals were observed in the field, but very small amounts of a red mineral thought to be cinnabar and of metallic quicksilver were observed in several heavy liquid concentrates of the rock from the deposits. It seems likely that the quicksilver and cinnabar are contamination from the crushing machine or sieves that were used in preparing the samples. Because of the small amount of quicksilver present it was not thought significant.

\section{STOCKWORK}

The molybdenite deposits of the Nunatak area are of two typesa stockwork type and a fault type.

The stockwork is by far the largest deposit. It embraces all the diopside-rich contact aureole described above and extends outward 
beyond its limits but not inward into the intrusive core or its silicified outer parts. The stockwork as herein defined is that part of the zone of quartz veinlets already mentioned in which molybdenite is prevalent.

The zone of quartz veinlets, of which the stockwork is a part, is divisible into three parts: (1) An outer zone having a few quartz veinlets, (2) an intermediate zone, the stockwork, consisting of numerous anastomosing quartz veinlets, some of which carry molybdenite, and (3) a narrow envelope of almost completely silicified material at the outer borders of the quartz monzonite porphyry. The boundaries of the three zones are gradational and would undoubtedly be mapped somewhat differently by different persons. Neither the siliceous envelope nor the outer zone contains visible molybdenite except for a few scattered localities too small to show on the map. The numerous quartz veinlets that cut the hornfels and parts of the intrusive stock range in thickness from a fraction of an inch to as much as 9 inches. Most of the veinlets are between 1 inch and 2 inches thick. The veinlets, which increase in number toward the intrusive, comprise about 25 percent of the rock mass. The veinlets, particularly in the intermediate zone, cut the rock in all directions, but a preferred direction of $\mathrm{N} .65^{\circ} \mathrm{W}$. is recognizable.

Much of the area over which the stockwork crops out is steep with a maximum relief of about 1,100 feet above sea level. The deposit is covered by moraine in its northwestern part. To the northwest the deposit passes beneath Muir Inlet and to the northeast beneath an extensive moraine fringing a large mass of stagnant ice.

Where the zone of quartz veinlets projects conspicuously northwestward to Muir Inlet it contains most of the richer parts of the stockwork. In this part of the zone the bedrock has been folded into a well-defined anticline. The northwestward projection of the zone of veinlets may indicate that the quartz monzonite is at no great depth below the surface.

\section{FAULT DEPOSITS}

Several faults within the zone of quartz veinlets contain conspicuously more molybdenite than their wall rocks. The fault deposits are similar to the stockwork in that molybdenite is present generally along the margins of the quartz veinlets, but they differ from it principally in containing many open fractures, in containing molybdenite in thicker masses, and in being locally almost completely epidotized. The deposit along the Nunatak fault is particularly large and well mineralized.

In addition to the Nunatak fault deposit three other fault deposits are large and well mineralized. A few smaller and less mineralized faults will not be discussed. 
The Nunatak fault deposit crosses the eastern part of the stockwork. The other three deposits lie east of the Nunatak fault, two of them within the stockwork and the third outside the stockwork but within the zone of quartz veinlets near its outer margin.

The Nunatak fault deposit crops out for a length of 2,000 feet. It disappears to the north beneath talus and moraine and to the south beneath moraine and a small lake. The known vertical range of the deposit is from about 380 feet to about 910 feet above sea level. Its width ranges from about 5 feet to as much as 20 feet and averages about 9 feet. The fault strikes about N. $5^{\circ}$ E., and its dip steepens from $60^{\circ} \mathrm{E}$. in its southern part to $75^{\circ} \mathrm{E}$. at its northernmost exposure. The other fault deposits are approximately vertical and strike more eastward than the Nunatak fault deposit. They are a few tens of feet long and average about 3 feet wide.

The quartz veinlets that cross the fault zones are similar in most respects to the quartz veinlets elsewhere. The veinlets are better mineralized in the fault zones and seem to indicate that earlier fault movements formed places particularly favorable for molybdenite deposition. Recurrent movements along the faults have shattered the rock and the quartz veinlets and have displaced for short distances many postmineral dikes.

\section{ORIGIN OF' THE DEPOSITS}

The close association of the quartz veins and their contained molybdenite with the quartz monzonite porphyry, and the fact that the zones of mineralization surround the intrusive stock indicate that the mineralization is genetically related to the stocklike body. It may be inferred that the small stocklike body now partly exposed is a cupolalike portion of a much larger body not exposed. Apparently, molybdenum-bearing fluids were liberated from lower portions of the igneous body and were deposited in the fractured rock that surrounds the instrusive. There is no apparent structural evidence to indicate why the locality of the present deposit was particularly favorable for igneous intrusion and consequent mineralization. Other deposits of molybdenite that have been described ${ }^{\top}$ are in or near igneous rocks and are regarded as genetically related to those rocks.

The fact that the siliceous outer parts of the intrusive mass grade inward into quartz veinlets penetrating the intrusive rock and far outward into the hornfels to form the zone of quartz veinlets indicates that the outer parts of the intrusive body may have contained the channels through which the silica-bearing solutions moved upward from depth.

\footnotetext{
${ }^{7}$ Butler, B. S., and Vanderwilt, J. W., The Climax molybdenum deposit, Colorado: U. S. Geol. Survey Bull: 846-C, pp. 233-236, 1933.
} 


\section{RESERVES}

GRADE

All the molybdenite deposits of the Nunatak area are of very low grade. Two grades of molybdenite-bearing rock have been recognized and are represented on the geologic map. (See pl. 2.) The material with conspicuous molybdenite, and so designated on the geologic map, crops out over an area of about 170,000 square feet and contains enough molybdenite to be readily apparent even on casual inspection. Material designated as containing inconspicuous molybdenite crops out over an area of about 2,000,000 square feet and has so little molybdenite that it is revealed only by close examination. The distinction between the two types may not be everywhere consistent.

The grade of the two types of material no doubt varies widely from place to place. Considerable information on grade, particularly in regard to the material mapped as containing conspicuous molybdenite, has been contributed by the Bureau of Mines. The Bureau of Mines party systematically collected a total of $249 \mathrm{chip}$, drill, and channel samples. Of these samples, 16 were taken from the Nunatak fault and 233 from the northwestern part of the stockwork.

The 177 samples from a part of the stockwork mapped as containing conspicuous molybdenite contain from 0.02 to 0.21 percent of molybdenum, except for 2 that are very much richer and contain 0.26 and 0.52 percent of molybdenum. The numerical average of the results is 0.075 percent. The 56 samples collected by, the Bureau of Mines from material mapped as containing inconspicuous molybdenite contain from 0.02 to 0.11 percent of molybdenum, and the numerical average of the results is 0.048 percent of molybdenum. The samples from the Nunatak fault deposit contain from 0.04 to 0.34 percent of molybdenum with a.numerical average of 0.102 percent.

Because the bright flakes and surfaces of molybdenite contrast strongly with their enclosing material the molybdenum content of the rock appears to be considerably greater than is indicated by the analytical results.

\section{TONNAGE}

For estimating tonnage the Nunatak fault deposit, which crops out over a vertical distance of about 500 feet, is assumed to extend to an average depth of about 300 feet and to have an average width of 9 feet and a length of 2,000 feet. Assuming a factor of 10 cubic feet to a ton, the Nunatak fault deposit contains about 500,000 tons of indicated molybdenite-bearing material of which, on the basis of surface mapping, 280,000 tons contain conspicuous molybdenite. Probably the Nunatak fault deposit extends to a greater depth than 300 feet, but to 
be conservative that depth has been used for computations rather than some greater depth.

The stockwork crops out over an area of about 2,170,000 square feet and over a vertical distance of about 1,100 feet. It is assumed, for estimating tonnage, that the stockwork extends to an average depth of not less than 500 feet. On this basis the deposit contains about $100,000,000$ tons of indicated molybdenite-bearing material, of which, on the basis of surface mapping, about $8,500,000$ tons contain conspicuous molybdenite. Of this latter quantity about 1,200,000 tons are estimated to be above sea level.

The actual extent of the deposit below the present surface is unknown except for meager data furnished by two short holes drilled by the Bureau of Mines in the northwest part of the deposit, the deeper of which reaches about 169 feet below the surface or about 150 feet below sea level. However, because of the large vertical range of its outcrop, the stockwork is thought to continue to a depth of many hundreds of feet below the surface. Because the intrusive mass probably is larger in depth and because the stockwork surrounds the mass, the area of the stockwork may increase with depth.

If estimates are made without allowing for expansion of the stockwork downward the following table indicates roughly the tonnages in the several deposits for each 10 feet of depth.

Possible tonnages of molybdenite-bearing material in deposits of the Nunatak area, Glacier Bay, southeastern Alaska

\begin{tabular}{l|r|r}
\hline \multicolumn{1}{c|}{ Deposit } & \multicolumn{2}{|c|}{ Tons per 10 feet of depth } \\
\hline $\begin{array}{l}\text { Part mapped } \\
\text { as containing } \\
\text { conspicuous } \\
\text { molybdenite }\end{array}$ & $\begin{array}{l}\text { Part mapped } \\
\text { as contain ng } \\
\text { inconspicrous } \\
\text { molybdenite }\end{array}$ \\
\hline $\begin{array}{l}\text { Stockwork. } \\
\text { Nunatak fault. }\end{array}$ & $\begin{array}{r}170,000 \\
10,000\end{array}$ & $\begin{array}{r}2,000,000 \\
8,000\end{array}$ \\
\hline
\end{tabular}

ECONOMIC CONSIDERATIONS

The price of molybdenite has been about 75 cents per pound of molybdenum for the past several years, and at that price the molybdenite deposits of the Nunatak area apparently could not be mined at a profit.

Any plan to undertake mining operations at the Nunatak or in the Glacier Bay area will need to take into account the difficulty of obtaining in adequate labor supply in this remote locality, the lack of usable timber within a radius of 50 miles, the heavy winter snows, and the lack of a fresh water supply. The topographic position of the deposit and 'its aceessibility by small boat on stealmen favor development. 


\title{
MOLYBDENITE DEPOSIT AT SHAKAN, KOSCIUSKO ISLAND
}

\author{
By G. D. RoBinson
}

\section{INTRODUCTION}

Shakan is an abandoned cannery village on the east shore of Shakan Bay, near the north end of Kosciusko Island, southeastern Alaska. (See fig. 1.) It is about 65 miles by water southwest from both

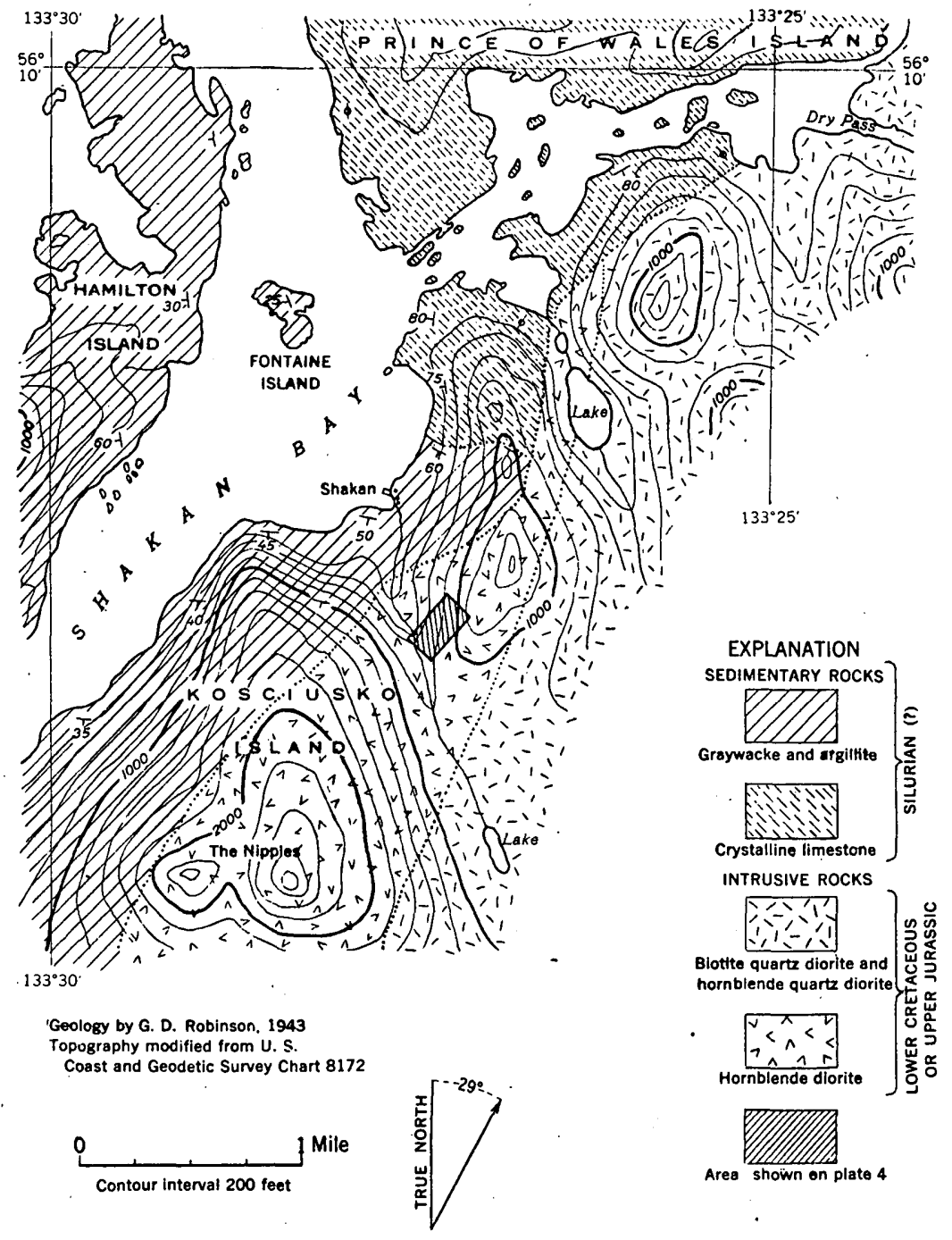

Figdre 2.-Geologic reconnaissance map of vicinity of Shakan molybdenite deposit, Kosciusko Island, southeastern Alaska.

$689318-46-3$ 
Wrangell and Petersburg, the nearest ports. The molybdenite deposit (see fig. 2) is three-fifths of a mile south of Shakan at an altitude of 690 feet. The deposit is near the head of the large valley south of Shakan and can be reached with little difficulty, although there is no well-defined trail.

Northern Kosciusko Island is rugged, and below 2,000 feet it is heavily timbered with hemlock and spruce. Locally, dense growths of devils club and alder impede travel. Talus, glacial till, and vegetation cloak most of the surface, and rock outcrops are rare. The climate is mild and humid.

During and shortly after the First World War the Alaska Treadwell Gold Mining Co. developed the property, driving 570 feet of tunnel and excavating 14 surface cuts. A compressor was installed, and a tramway, docks, and camp were built; these improvements are no longer usable. Nearly 200 analyses were made of samples from the tunnel and the open cuts, and they form the basis of the grade estimates in this report. After the war, development stopped with the drop in price of molybdenum, and no ore was shipped.

The Alaska Juneau Gold Mining Co. now owns the property that includes 11 patented lode claims and 4 mill-site claims.

During the development period, the deposit was the subject of private reports.by R. G. Wayland and Livingston Wernecke of the Alaska Treadwell Gold Mining Co. and was briefly examined and described by J. B. Mertie, Jr., ${ }^{8}$ and Theodore Chapin ${ }^{9}$ of the Geological Survey. More recently, A. F. Buddington ${ }^{10}$ presented the results of a laboratory study of specimens from the deposit. The Bureau of Mines ${ }^{11}$ examined the deposit in 1942 and announced plans to explore and develop it. The proposed work had not been started in April 1945.

This report summarizes field work done by the Geological Survey during the period from August 1 to September 3, 1943. The field party consisted of G. D. Robinson and R. A. Harris, geologists, and J. A. Bollen, camp hand. The underground workings were mapped on a scale of 1 inch equals 10 feet.' The surface workings and the immediate vicinity of the deposit were mapped on a scale of 1 inch equals 100 feet and contoured on an interval of 50 feet, using the open-sight alidade-tape method. As a field setting for the mine area, about 10 square miles of northern Kosciusko Island and adjacent Hamilton, Fontaine, and Prince of Wales islands were mapped on a scale of 1 inch equals 3,300 feet.

\footnotetext{
${ }^{8}$ Mertie, J. B., Jr., Lode mining in the Juneau and Ketchikan districts: U. S. Geol. Survey Bull. 714-B, pp. 118-119, 1921.

o Chanin, Theodore, Mining developments in the Ketchikan district: U. S. Geol. Survey Bull. $692-$ B, p. 89, 1919.

${ }^{10}$ Buddington, A. F., Molybdenite deposits at Shakan, Alaska : Econ. Geol., vol. 25, pp. 197-200, 1930 .

${ }^{11}$ Bureau of Mines, Shakan molybdenum deposit: War Minerals Rept. 108 (restricted), 9 pp., March 1943.
} 
Mr. P. R. Bradley of the Alaska Juneau Gold Mining Co. very kindly furnished the analytical data used. Mr. J. C. Reed and Mr. W. S. Twenhofel gave assistance both in the field and in the office. The writer is indebted to Mr. and Mrs. Steve Chernoff of Fontaine Island and to Mr. E. P. Hamilton of Calder Bay for many kindnesses.

\section{REGIONAL GEOLOGY}

A.thick sequence of massive white crystalline limestone, exposed along the east shore of Shakan Bay north of Shakan and extending eastward into Dry Pass, conformably underlies a thick sequence of dark thin-bedded graywacke and argillite, exposed along the shore south of Shakan and on Hamilton and Fontaine islands. (See fig. 2.) As recognized by Buddington and Chapin, ${ }^{12}$ these rocks are probably on the eastern limb of a large, complexly crumpled syncline trending north-northwestward and are probably of Silurian age.

The sediments are intruded by a large intrusive stock, of which only a small part is in the mapped area. Biotite-quartz diorite and subordinate hornblende-quartz diorite are exposed along Dry Pass, probably occupy most of the valley east of the hills flanking the prospect area, and extend for unknown distances to the south and east. A belt of hornblende diorite borders the quartz diorite on the west, separating the quartz diorite from the graywacke-argillite sequence and in part from the limestone sequence. The contact between the graywacke-argillite beds and the hornblende diorite is transitional, suggesting much interaction between the sediments and the intrusive fluids. The relative ages of the intrusives are not known. The sediments and the stock are cut by many dikes, including granite aplite, granite pegmatite, dacite, andesite, basalt, and lamprophyre. The intrusives are probably contemporaneous with those on the mainland comprising the Coast Range batholith of Upper Jurassic or Lower Cretaceous age.

\section{MOLYBDENITE DEPOSIT}

\section{GENERAL DESCRIPTION}

The molybdenite deposit is in a narrow brecciated fault zone near the middle of the belt of hornblende diorite. (See fig. 2.) Molybdenite is sparsely disseminated in the diorite in a few places far beyond the zone, but significant mineralization appears to be confined to the fault zone and to the immediately adjacent country rock.

The fault zone ranges in thickness from less than 1 foot to more than 10 feet and has an average thickness of 4 feet. (See pls. 4 and 5.) The zone persists throughout the length of the tunnel and has been

\footnotetext{
12 Buddington, A. F., and Chapin, Theodore, Geology and mineral déposits of southeastern Alaska : U. S. Geol. Survey Bull. 800, p. 308, 1929.
} 
traced on the surface for about 800 feet. In detail the strike of the fault zone ranges widely and abruptly. The average strike in the western part of the tunnel is about $\mathrm{N} .85^{\circ} \mathrm{W}$. and in the eastern part about N. $70^{\circ}$ E. The few surface exposures strike similarly. Dips average between $20^{\circ} \mathrm{S}$. and $25^{\circ} \mathrm{S}$. in the western part of the tunnel and between $10^{\circ} \mathrm{S}$. and $15^{\circ} \mathrm{S}$. in the eastern part; short segments of the zone have dips as great as $35^{\circ}$ and as small as $5^{\circ}$. Dips on the surface range from $20^{\circ} \mathrm{S}$. to $35^{\circ} \mathrm{S}$., although one questionable dip of $15^{\circ} \mathrm{S}$. is recorded. In most places the zone is bounded by fractures filled with gouge, generally about 1 inch thick but locally as much as 6 inches thick. In some places either or both of the limiting fractures feather out into many irregular fractures with little or no gouge, and the limits of the zone are indefinite. Breccia blocks of hornblende diorite, ranging from less than 1 inch to more than 30 inches in maximum dimension, are the principal material filling the zone. The diorite fragments are separated by bands, generally less than 1 foot thick, of igneous and hydrothermal materials introduced at various times during repeated reopenings of the fault zone, and by silicified gouge. Some irregularly shaped masses of introduced material are as much as 4 feet wide and more than 10 feet long. Included in the introduced matrix are granite pegmatite; quartz-adularia, quartz, and calcite veins; lamprophyre and aplite dikes; zeolite encrustations; and iron, copper, zinc, and molybdenum sulfides and their decomposition products. The fault zone constitutes a composite vein.

\section{ORE MINERALS}

Molybdenite $\left(\mathrm{MoS}_{2}\right)$ is the only mineral present in economic quantities. It occurs as disseminated fine grains, as crystals in cavities still partly open, as coatings on crystals of other minerals, and, more rarely, in veinlets. Other sulfide minerals in the vein, in order of decreasing abundance, are pyrite, pyrrhotite, chalcopyrite, and sphalerite. These minerals are generally intergrown in small irregular masses nearly free from other minerals. In addition, pyrite is a very common vein constituent, and chalcopyrite, pyrrhotite, and sphalerite are in a few veins. Negligible amounts of gold are reported in analyses.

Weathering of the sulfide minerals has produced small amounts of molybdite $\left(\mathrm{Fe}_{2} \mathrm{O}_{3} \cdot 3 \mathrm{MoO}_{3} \cdot 71 / 2 \mathrm{H}_{2} \mathrm{O}\right)$, limonite, hematite, and chalcanthite $\left(\mathrm{CuSO}_{4}-5 \mathrm{H}_{2} \mathrm{O}\right)$.

The ore minerals with their decomposition products aggregate about 5 percent of the vein filling.

\section{GANGUE}

The principal gangue is the diorite breccia previously described. which aggregates more than half the waste. The breccia fragments 
are in many places marginally replaced by sulfide minerals and by gangue minerals.

At some places, particularly in the eastern part of the tunnel, a hard, dark, fine-grained, banded rock occupies part of the vein. The banding parallels the vein boundaries. This material probably represents gouge developed during brecciation previous to or accompanying mineralization and hardened by addition of silica.

About half the introduced gangue is pegmatite, consisting mainly of pink orthoclase but containing some quartz, biotite, muscovite, and sphene. The pegmatite is coarse-grained, contains many vugs, and is much crushed.

Vuggy, intricately fractured quartz-adularia yeins and masses are. common, although less abundant than pegmatite. In addition to clear glassy quartz and white euhedral adularia, the rock contains well-formed crystals of bright-green epidote. The proportions of quartz and adularia vary widely.

Veins and masses of pink calcite and of clear and cloudy quartz are numerous. Small lamprophyre and aplite dikes appear sporadically in the vein. Some fractures and cavities are lined with zeolite crystals, principally laumontite $\left(\mathrm{CaO} \cdot \mathrm{Al}_{2} \mathrm{O}_{3} \cdot 4 \mathrm{SiO}_{2} \cdot 4 \mathrm{H}_{2} \mathrm{O}\right)$.

The vein materials are in general distributed at random with reference to the boundary walls. They are all present above the mapped hanging wall and below the mapped footwall but are much more abundant between these surfaces. Laterally, the relative proportions of the vein materials range widely on both a large and a small scale. The large-scale differences in mineral proportions are. shown on plate 5 .

\section{COUNTRY ROCK}

The hornblende diorite country rock ranges widely in grain size and in the relative proportions of light and dark minerals. According to Mertie ${ }^{13}$ the rock "varies somewhat in character and composition but in general is composed of zonally grown plagioclase feldspar * * * with an average composition perhaps of andesine; a small amount of orthoclase; considerable hornblende; and biotite, augite, iron oxides, and apatite." Inclusions that appear to be partly digested graywacke and argillite fragments are abundant.

\section{TIME RELATIONS}

Only preliminary microscopic work has been done by the writer. The tentative statements that follow are based mainly on field examination. However, the writer's conclusions generally agree with those of Buddington.

13 Mertie, J. B., Jr., op. cit. 
The sequence of mineralization appears to have been as follows: Pegmatite was first introduced, orthoclase preceding quartz. Some of the clear quartz veins were next deposited, accompanied by pyrite. For a time, adularia and, somewhat later, epidote were deposited, along with quartz and pyrite. The lamprophyre and aplite dikes were probably intruded at this stage. Sphalerite, pyrrhotite, chalcopyrite, and molybdenite were next deposited, being first introduced in the order given. Pyrrhotite precedes sphalerite in most deposits elsewhere, but it definitely veins and replaces sphalerite in this deposit. Calcite was next deposited, perhaps contemporaneously with part of the molybdenite. Much cloudy quartz and some clear quartz were deposited after the calcite. Later, zeolites were formed.

During mineralization the feldspars were partly altered to sericite and kaolin, the epidote was partly altered to chlorite, and the hornblende was partly altered to biotite and chlorite.

Figure 3 illustrates diagrammatically the probable sequence of mineralization.

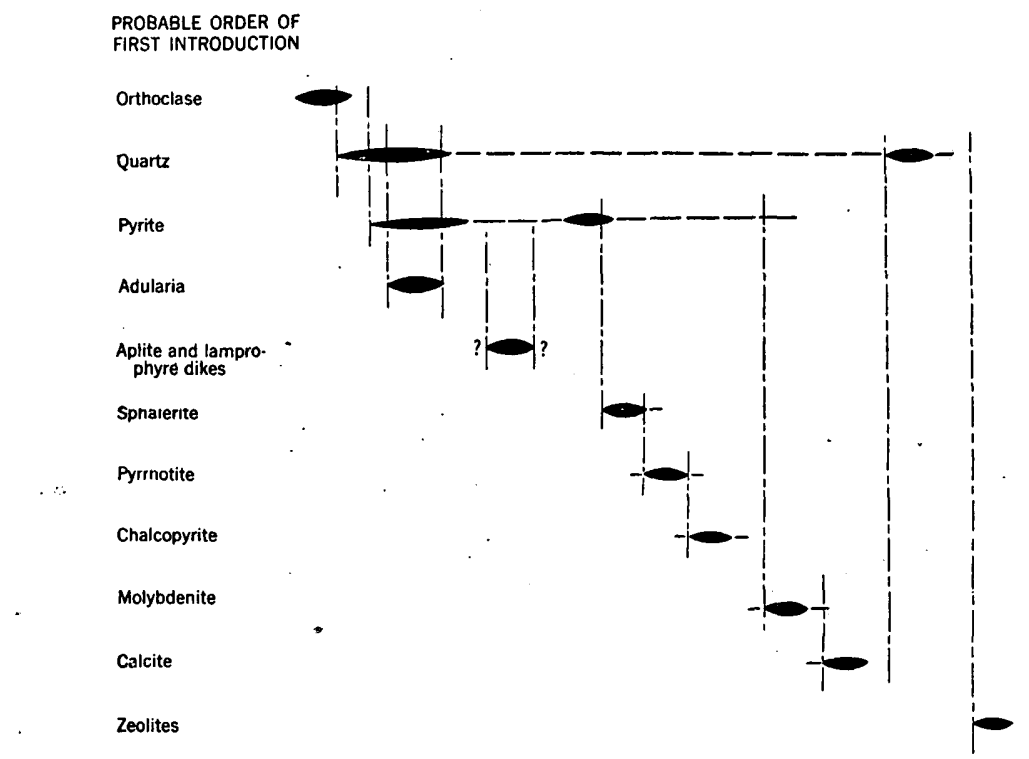

Figrin: 3.-Diagram showing probable sequence of mineralization, Shakan molybdenite deposit, Kosciusko Island, southeastern Alaska.

\section{ORIGIN}

'The introduced vein materials were deposited from ascending solutions, probably during the late stages of the process that earlier formed the hornblende diorite.

The tempepatunes at which the molybdenite was deposited can be established only within very broad limits. It is generally agreed that 
granite pegmatites form at temperatures approaching $575^{\circ} \mathrm{C}$. and that zeolites form only at temperatures below $200^{\circ} \mathrm{C}$. If it is assumed that the sequence of introduction and deposition was a continuous process, which being near the end of an igneous cycle was accompanied by steadily decreasing temperature, it follows that molybdenite was deposited at temperatures closer to $200^{\circ} \mathrm{C}$. than to $575^{\circ} \mathrm{C}$. However, as all the pre-molybdenite materials can form at rather high temperatures, it is possible that the molybdenite was deposited at much higher temperatures than $200^{\circ} \mathrm{C}$.

Regarding temperatures of deposition, Buddington ${ }^{14}$ says:

The vein deposit under discussion is obviously of composite origin, ranging from minerals of the pegmatite stage $\left(578^{\circ}+\right.$ C. $)$ to those of the zeolite stage $\left(50^{\circ}-200^{\circ} \pm\right.$ C. $)$. The minerals of the adularia period appear to follow the pegmatite stage and to be best grouped, following Lindgren's classification, as of hypothermal origin. Insofar as the sulphide minerals themselves are concerned, they might belong to either the hypothermal or mesothermal veins; but since, with the exception of pyrite, they follow for the most part the adularia period and are succeeded by the zeolites, it would seem that they are best grouped as belonging to the mesothermal period, and the minerals of the zeolite period as formed in an epithermal stage.

Some of the older vein constituents, particularly pegmatite and pyrrhotite, are generally supposed to form at relatively high pressures. However, the abundance of vugs and open fractures, the intricacy of brecciation, and the small amount of replacement as compared with fracture filling observed throughout the deposit are strongly suggestive of low pressures.

If the conclusion is valid that the minerals were deposited over a wide temperature range at low pressures, that is, at relatively shallow depths, it is difficult to place the Shakan molybdenite deposits in the Lindgren classification. The deposit seems to fit most readily in the xenothermal type proposed by Buddington..$^{15}$ However, Buddington, despite his earlier study of Shakan specimens, does not include the deposit among his examples of the xenothermal type and specifically cites pyrrhotite and adularia, both common at Shakan, as being rarely present in xenothermal deposits.

\section{STRRUTURE}

Small-scale faulting evidently occurred repeatedly during min-eralization. Only the limiting faults and a prominent cross fault are mapped. (See pl. 5.)

The faults that limit the vein are well-defined fractures that probably were developed before the mineralization. There has been some

\footnotetext{
${ }^{14}$ Brddington, A. F. : Molybdenite deposits at Shakan, Alaska : Econ. Geol., vol. 25, p. $\therefore 200,1930$.

${ }^{15}$ Buddington, A. F. : High-temperature mineral associations at shallow to moderate depths: Econ. Geol., vol. 30, No. 3, pp. 205-222, 1935.
} 
postmineralization movement along the boundary faults, as is indicated in the gouge by fragments of sulfide minerals and introduced gangue minerals. The amount and nature of the boundary-fault displacements is not definitely known. The effective displacement is believed to be small, perhaps not exceeding a few feet, as indicated by the small range in thickness of the vein, in comparison with the large range in strike and dip. In the tunnel the thicker parts of the vein are in general the more steeply dipping parts. For this reason it is supposed that the effective displacement was of the normal type, the south (hanging) wall having moved down relative to the north (foot) wall.

West of the tunnel portal the fault zone appears to be much thinner and may disappear in places between the portal and the most westerly exposure in the creek.bed, where it is poorly developed and not more than 2 feet thick. Although the zone thins to about 2 feet in cuts 10 to 13 (see pl. 4) near the east end of the exposures, cut 14 shows a vein thickness of nearly 6 feet, and the zone probably continues somewhat farther. No great continuation of the zone beyond the present limits can be safely predicted.

A cross fault offsets the vein in the adit, about 260 feet from the portal. This fault is nearly vertical and strikes about N. $5^{\circ} \mathrm{E}$. The west wall has an apparent upward displacement of a bout 5 feet and a southward displacement of about 15 feet, relative to the east wall.

\section{FACTORS INFLUENCING MOLYBDENITE DISTRIBUTION}

The analyses, as shown on plate 6 , indicate that the molybdenite content of the vein is relatively high in the open cuts and at the west end of the adit and negligible or relatively low in the remainder of the adit. In those portions of higher molybdenite content the vein dips more steeply and contains higher proportions of pegmatite and quartz-adularia than in the portions of lower molybdenite content.

The well-mineralized part of the vein on the adit level dips from $20^{\circ}$ to $35^{\circ} \mathrm{S}$. The poor condition of the surface cuts precludes accurate dip determinations, but the few dips taken range from $20^{\circ}$ to $35^{\circ} \mathrm{S}$. except in cut 8 , in which the dip is about $15^{\circ} \mathrm{S}$. The barren and poorly mineralized parts of the vein in the adit generally dip from $5^{\circ}$ to $15^{\circ} \mathrm{S}$, although one dip of $20^{\circ} \mathrm{S}$. is recorded. If the effective displacement of the vein walls was of the normal type, as previously suggested, the vein fractures would have been relatively open in more steeply dipping portions and relatively closed in less steeply dipping portions, and the steeper, open parts would have been favorable places for mineral deposition. This may explain the failure of ore exposed on the surface between cuts 6 and 14 to continue down dip to the eastern parts of the adit level. Comparison 
of dip data with analyses (see pls. 4 and 6) shows that the relation between steeper dip and better ore is not constant and may prove to be merely local. However, this relation may be of value as a guide to ore and should be kept in mind during any future development.

Pegmatite and quartz-adularia are the dominant vein fillings in the richer exposed parts of the vein. Molybdenite has been reported in many localities elsewhere as an accessory mineral in granite pegmatite, with an implied genetic relationship. In this deposit many events clearly separate the pegmatite phase from the molybdenite phase in time, and the spacial relationship is not genetic except in the broadest sense. Molybdenite cuts and coats other sulfides, lamprophyre dikes, vein calcite, and vein quartz, all of which are younger than the pegmatite and quartz-adularia. At least two periods of fracturing intervened between the phases involved. It is believed that mineralization is more intense in the pegmatite and quartzadularia for structural reasons only. The kind of movement that produced the openings localizing the gangue appears to have been repeated prior to the introduction of molybdenite and thus to have produced similarly placed openings for the passage of molybdenitebearing solutions. Moreover, the rocks in question contain numerous vugs and fractures in which molybdenite could readily be deposited from passing solutions.

The fault zone was doubtless the principal channel for the mineralizing fluids. At the time of molybdenite introduction the zone was apparently not bounded by much gouge, and some molybdenite was deposited beyond the limiting fractures.

\section{RESERVES}

\section{GRADES AND DIMENSIONS OF ORE SHOOTS}

The determination of the grades and dimensions of minable segments of the vein presents a number of problems. Because the molybdenite content ranges widely and abruptly, the limits of economic mineralization within the vein are assay limits and cannot be located accurately. Although most molybdenite is between the mapped hanging wall and footwall, minable concentrations are present locally a few feet beyond these walls near some of the richer parts of the vein.

Measurements and analyses used herein are from' records of the Alaska Juneau Gold Mining Co. (see pl. 6), with the exception of a single sample collected and analyzed by the Bureau of Mines. All the analyses of the Alaska Juneau Gold Mining Co. were made in the period 1917-21. The following data illustrate the wide range 
in results obtained by different analysts in that period. ${ }^{16}$ Parts of the same sample from each of the open cuts were analyzed by the developing company and by two commercial analysts. The molybdenite content of five of these samples is listed in the following table:

Analyses, of molybdenite by the Alaska Juneau Gold Mining Co. and two commercial analysts during period 1917-21

\begin{tabular}{|c|c|c|c|}
\hline \multirow{2}{*}{ Cul from which sample was taken } & \multicolumn{3}{|c|}{ Percentage of $\mathrm{MoS}_{2}$} \\
\hline & Alaska Juneau & Abbot Hanks & $\underset{\text { Emith \& }}{\text { Smith }}$ \\
\hline $\begin{array}{l}1 \\
8 \\
7 \\
8\end{array}$ & $\begin{array}{r}0.94 \\
.86 \\
.75 \\
.28 \\
.68\end{array}$ & $\begin{array}{l}1.11 \\
2.56 \\
1.05 \\
.30 \\
2.61\end{array}$ & $\begin{array}{r}1.36 \\
1.50 \\
.61 \\
.50 \\
.61 \\
\end{array}$ \\
\hline A verage & .70 & 1.53 & .92 \\
\hline
\end{tabular}

No information is available to the Geological Survey as to the analytical methods used and it cannot be stated which group of results is the most nearly correct. The results of the Alaska Juneau Gold Mining Co. are consistently low in comparison with the others.

In the discussion of grade that follows, the cut-off used in calculations has been arbitrarily set at 0.5 percent of $\mathrm{MoS}_{2}$.

There is little agreement among the three sets of analyses made of adit samples. These samples taken in group $A$ of plate 6 represent an attempt to test the deposit between the boundary fractures of the vein. They are moil samples taken 5 feet apart from all portions of the tunnel containing visible molybdenite.

Samples of group B were apparently taken to check the grade of the richer part of the vein. The samples are moil samples taken 10 feet apart across the entire height of the adit, which in most places is several feet greater than the width of the vein. At most places "top" and "bottom" samples were taken for group B. The division apparently was made for the purpose of discriminating between the $\mathrm{MoS}_{2}$ content of a pegmatite dike, which intermittently follows the hanging wall in this part of the adit, and the content of the remainder of the vein. Most of the top samples contain more molybdenite than the corresponding bottom samples. The difference is in part attributable to the fact that bottom samples extend from a few inches to a few feet below the footwall of the vein.

During the driving of the first 220 feet of the adit, between three and five "face samples"-Group C-were taken for each 10 feet of adit, The width of each sample is not recorded, and only a numerical average can be calculated for this group.

Although samples of group B (top and bottom combined) are considerably longer than those of group A, the average molybdenite con-

${ }^{16}$ Bradley, P. R., letter of Dec. 27, 1943. 
tent reported for group B (1.85 percent) is much greater thain that reported for group A (1.17 percent) for nearly the same footage. The average molybdenite content reported from group $\mathrm{C}$ (2.83 percent) is nearly $21 / 2$ times that reported for group $\mathbf{A}$ and more than $1 \frac{1}{2}$ times that reported for group B.

Only one complete set of analyses of surface samples is available.

To choose among the three groups does not seem advisable, and to compute an average directly from them is not' worth while because the groups are not entitled to equal consideration. The metallurgical sample taken by the Bureau of Mines provides the only recently taken check of grade. The sample was "taken from the wall of the adit between 164 and 167 feet and from hanging wall to footwall." ${ }^{17}$ The sample contained 2.92 percent of $\mathrm{MoS}_{2}$.

It is apparent that a precise statement of ore grade cannot now be made. In the writer's opinion, analyses of group $\mathrm{C}$ are too high, and the true grade of the ore in the adit is approached by groups $A$ and $B$.

Regardless of the true grade of ore, it is evident from inspection of analyses of giroup A that a segment of the vein near the west end of the adit has a relatively high molybdenite content, that a short segment at the east end has a relatively low molybdenite content, and that the remainder of the vein on the adit level is essentially barren. For estimating reserves, the ore is assumed to begin 50 feet from the portal and to continue 170 feet along the adit, or 155 feet measured on the average vein strike. The average thickness of the vein in this segment is 4.5 feet, as measured by the writer. However, some of the ore extends beyond the vein walls, and it is estimated that the average ore thickness is not less than 5.5 feet. The grade is believed to be about 1.5 percent of $\mathrm{MoS}_{2}$.

A weighted average of analyses of group A from the last 40 feet of the adit indicates 0.58 percent of $\mathrm{MoS}_{2}$ over an average sampled thickness of 4.5 feet. Both the individual analyses and inspection of the vein indicate that molybdenite distribution is particularly spotty in this portion.

Twenty-one irregularly spaced samples taken from surface exposures in the 520-foot interval between the portal and cut 14 contain a weighted average of 0.99 percent of $\mathrm{MoS}_{2}$ over an average sampled thickness of 4.0 feet. Several samples do not represent the full thickness of the vein, and apparently none test the country rock immediately adjacent to the vein.

Relating the data from the adit to those from the surface is diffcult, unless it is assumed that change in dip was the principal controlling influence on ore distribution. On this basis, the exposures of ore on the surface and at the west end of the adit appear as parts of a single irregularly bounded ore shoot.

17 Bureau of Mines, op. cit., p. 4. 
The orientation of the shoot cannot be determined satisfactorily. Its long axis probably trends between $\mathrm{N} .20^{\circ}$ and N. $60^{\circ} \mathrm{E}$. Its plunge is between $15^{\circ}$ and $30^{\circ} \mathrm{S}$. Its plunge length from cut 14 to the adit is between 450 feet and 500 feet, and the shoot probably continues at least a few tens of feet beyond cut 14 and below the adit. The strike length of the shoot in the vicinity of the adit is about 155 feet. The shoot doubtless pinches and swells and its strike length away from the adit is not known. The average thickness of the shoot is assumed to be 5 feet and the average grade 1.5 percent of $\mathrm{MoS}_{2}$.

The low-grade molybdenite-bearing zone at the east end of the adit may be on the periphery of a second ore shoot of indeterminate size and grade. However, it is equally likely that it is part of an area of slight molybdenite concentration in a low-dipping and therefore relatively unfavorable portion of the vein.

\section{TONNAGE}

The estimation of tonnage in the Shakan molybdenite deposit is difficult, principally because information on the orientation, dimensions, and molybdenite content of the ore shoot or shoots is inadequate. However, it is reasonably certain that the vein between the ore zone in the western part of the adit and at least part of the surface exposures constitutes a body of ore classifiable as measured.

The vein segment bounded by the ore zone in the adit and approximately by cuts 1 to 5 comprises the principal volume of measured ore, as estimated in this report. This segment, outlined as block $\mathrm{A}$, plate 6 , has an area, in the plane of the vein, of about 11,000 square feet and a volume of about 55,000 cubic feet. Assuming a factor of 12 cubic feet to a ton, the mass contains about 4,500 short tons. Ore definitely extends beyond cut 5 and below the adit, and a certain volume of this ore is classifiable as measured, depending on the zone or influence attributed to each sample. However, all this additional ore is herein regarded as of the indicated class.

If the shoot is assumed to extend below the adit for at least half its strike length and also to extend at least a few tens of feet downward from the cuts in a direction normal to the line of outcrop, it appears that a tonnage two or three times greater than that of the measured ore is indicated.

On this basis, the measured and indicated reserves aggregate between 10,000 and 20,000 tons, containing about 1.5 percent of $\mathrm{MoS}_{2}$. About 500 tons of ore were removed in driving the tunnel and are now on the dump, partly mixed with about 2,000 tons of waste.

An additional few tens of thousands of tons may be inferred. The low-grade material near the face of the tunnel may represent an ore shoot, and blind shoots may be distributed in other parts of the vein.

According to the Bureau of Mines, ${ }^{18}$ "metallurgical tests indicate that a high-grade concentrate can be produced by flotation."

${ }^{18}$ Bureau of Mines, op. cit.. v. 9. 


\title{
MOLYBDENITE DEPOSITS ON BAKER ISLAND
}

\author{
By G. D. Robinson
}

\section{INTRODUCTION}

Baker Island is a small outer island of the Alexander Archipelago of southeastern Alaska. (See fig. 1.) It is about 140 miles by water west of Ketchikan, the nearest port and supply point, and 20 miles southwest of Craig, the nearest settlement. Molybdenite is known in many widely separated places in the east-central part of the island. The largest deposits are on the east coast about 1 mile south of the entrance to Port San Antonio. (See pl. 7.)

Port San Antonio is a fairly well protected anchorage for small boats. In southeasterly storms the outer portions of the port are not safe, and boats should anchor in the south arm of the port. ${ }^{19}$

Landings with skiffs can be made safely on a small beach about 4,500 feet south of Point St. Boniface. (See pls. 7 and 8.) A good trail follows the shore for about 1,600 feet southward from the landing beach to the principal molybdenite showings.

Camp buildings, including three small bunkhouses, a cook house, an assay office, and a house designed for storing diamond-drill cores, were constructed or rebuilt in 1943 near the landing beach.

Baker Island is mountainous, with the steep slopes, rounded summits, and U-shaped valleys characteristic of many of the smaller islands of southeastern Alaska. Mount Miramar, in the central part of the area mapped (see pl. 7), is about 2,000 feet high. The topography of the area shown on figure 5 is typical of the island. The coastline is irregular and rocky, with discontinuous cliffs a few tens of feet high broken by a few small-pebble and cobble beaches, usually at valley mouths. The land away from the coast rises in a series of steep, discontinuous scarps, commonly a few tens of feet high, separated by less steeply inclined surfaces a few tens or hundreds of feet wide. Many of the interscarp surfaces slope $20^{\circ}$ to $40^{\circ}$; a few are nearly horizontal.

The dense vegetation characteristic of lower altitudes on the inner islands of the archipelago is absent on Baker Island. Sparse growths of alder and of berry bushes border the larger creeks near their mouths and are dotted about the larger valley floors and interscarp slopes. Most of the slopes below an altitude of about 1,200 feet are timbered, principally with spruce, but including considerable hemlock and a little yellow cedar. Above 1,000 feet altitude the trees decrease

10 U. S. Coast and Geodetic Survey Chart 8158 is useful for navigation in the vicinity. 
rapidly in height, are more widely spaced, and a species of dwarf pine replaces the other trees. Moss and soil cloak practically all the gentler slopes and most of the ridge tops, but rock exposures are good along the beaches, in the beds of some creeks, and in the scarps.

The summer climate is cool and humid. Freezing temperatures are reported common from October through April, but temperatures near $0^{\circ} \mathrm{F}$. are rare. Snow is the main form of precipitation in December to February, and snowfalls are common in November and March.

Molybdenite near Port San Antonio is believed to have been first recognized in 1931 by J. G. Galvin. At that time the San Antonio Metals Co. was formed, and a number of claims were staked. M. M. Reese, mining engineer of Seattle, Wash., examined the deposits for the company in 1931. Diamond-drilling was started in the summer of 1932, and four inclined holes, between 156 and 396 feet long, were drilled. No further work was done by the San Antonio Metals Co., except for restaking the original claims in 1939. In June 1940, W. A. Richelsen, representing the Kennecott Copper Corp., examined the prospect. In the spring of 1943 the Kennecott Copper Corp. undertook a diamond-drilling program supervised by Mr. Richelsen. Seven inclined holes, with lengths ranging from 200 to 376 feet, were drilled. Operations were suspended in September 1943.

From June 17 to July 28,1943 , the area was examined as a part of the war-minerals investigations of the Geological Survey. The Survey party consisted of G. D. Robinson and R. A. Harris, geologists, and A. J. Bollen, camp hand. Operations by the Kennecott Copper Corp. were in progress at that time. The vicinity of the main molybdenite deposits was mapped in detail, and about 5 square miles between Port San Antonio and Lake Fortaleza were mapped in less detail. The geology along the shore from Point Fortaleza around Cape Bartolome, the south tip of the island, was mapped but is not included in this report.

Late in August, Robinson returned for a few days to record the progress of the diamond-drilling and to log the core obtained after the Survey party went away.

Mr. Richelsen and other officials of the Kennecott Copper Corp. extended many courtesies. The Survey party is indebted to many residents of Craig and especially to Mr. George Edenso and the Reverend Stuart Emery for numerous kindnesses.

A preliminary map of the deposits was issued separately by the Geological Survey in November 1943. The rock units differentiated thereon were based on field exnminition. Subsequent laboratory studies have made more precise designations possible. Plate 8 of this report is comparable to and supersedes the preliminary map. 


\section{GEOLOGY}

According to Buddington and Chapin ${ }^{20}$ the south half of Baker Island is underlain by a mass of leucocratic quartz diorite, of probable Upper Jurassic or Lower Cretaceous age, bordered on the southeast and north by Devonian sediments striking east to east-northeast. The sediments are described as part of a sequence, which includes a great thickness of "graywacke, conglomerate, slate, limestone, and, locally, chert, with associated volcanics, including andesitic lava, breccia, and tuff."

\section{SEDIMENTARY ROCKS}

Slightly recrystallized sedimentary rocks underlie about $1 \frac{1}{2}$ square miles in the northern part and a narrow coastal strip in the southern part of the area mapped in 1943. (See pl. 7.) These rocks consist principally of alternating thin beds of fine-grained dark arenaceous and calcareous argillite, and of dense dark argillaceous quartzite. Some of the beds mapped as argillite may be partly or wholy tuffaceous. The sequence includes a few beds of dark marble. The bedding and foliation in general strike about $\mathrm{N} .15^{\circ}$ E. and dip steeply eastward, but in the vicinity of the molybdenite deposits near the quartz diorite the beds strike about $\mathrm{N} .60^{\circ} \mathrm{W}$. and dip steeply northward. (See pl. 8.) An apparent thickness of nearly 10,000 feet of these rocks is exposed between Bucareli Bay and the south arm of Port San Antonio; the true thickness is probably much less because of undetected repetition of beds by folding and faulting.

\section{IGNEOUS ROCKS}

The north end of the leucocratic quartz diorite mass mapped by Buddington and Chapin underlies about $31 / 2$ square miles of the area mapped in 1943. This part of the mass, believed initially to have been a rather uniform ferromagnesian-poor quartz diorite, has been universally but unequally attacked by late-magmatic and postmagmatic solutions and now includes rocks ranging widely in composition and texture. Rocks mapped as silicified quartz diorite range gradationally from slightly silicified medium- to fine-grained light-gray biotitehornblende-quartz diorite, showing only microscopic evidence of alteration, to greatly silicified facies containing large proportions of patches and veinlets of bluish quartz in a greenish-white matrix of quartz, plagioclase, and epidote-group minerals, with minor calcite and chlorite. Most of the quartz diorite mapped shows an intermediate degree of alteration. It differs from the extreme varieties in contain-

\footnotetext{
${ }^{20}$ Buddington, A. F. and Chapin, Theodore, Geology and mineral deposits of southeastern Alaska : U. S. Geol. Survey Bull. 800, pp. 187, 311, and pl. 1, 1929.
} 
ing abundant pseudophenocrysts of bluish quartz as well as partially altered and replaced, though still identifiable, biotite and hornblende; it is herein designated pseudoporphyritic quartz diorite. The intensity of the alteration ranges considerably within short distances. In some places, outcrops a few tens of feet across show almost the entire gradational range. In general, however, the degree of alteration increases toward the northeast, and mappable areas mainly of greatly silicified quartz diorite are known only in the extreme northeastern part of the intrusive. (See pl. 8.) Mappable areas mainly of slightly silicified quartz diorite are known at the south end of the area shown on plate 8 and above about 700 feet altitude at the head of the south arm of Port San Antonio. No attempt has been made to separate quartz diorite facies on plate 7.

Preliminary microscopic examination indicates that the unaltered rock was composed of about 25 percent of quartz, 65 percent of zoned. plagioclase ranging from oligoclase to andesine, and 10 percent of biotite, hornblende, and accessory minerals. The rock was variably brecciated, probably a short time before complete solidification at the present surface of exposure, and attacked by solutions from stillliquid underlying parts of the intrusive. In parts only slightly attacked the principal effect was the deposition of quartz between breccia fragments, with a little marginal replacement of the silicate minerals and some saussuritization of the cores of plagioclase crystals. In more intensely altered parts replacement of silicate minerals was more pronounced; in addition to large proportions of introduced quartz, partly in fine-grained phenocrystlike aggregates, the rocks contain minor but significant proportions of albite, epidote-group minerals, chlorite, and calcite replacing part or all of the original plagioclase, biotite, and hornblende. All these changes are implied in the writer's use of silicification and similar words. The intensity of silicification can in general be correlated with the intensity of brecciation. Probably the breccia openings guided the movement of the silicifying fluids.

The quartz diorite is intricately broken by joints, most of which dip steeply. Joints of the more persistent sets, in approximate order of decreasing prominence, strike N. $60^{\circ}-70^{\circ}$ W., N. $10^{\circ}-20^{\circ}$ W., N. $5^{\circ}-20^{\circ} \mathrm{E}$., and $\mathrm{N} .80^{\circ}-90^{\circ} \mathrm{W}$.; for convenience these are referred to as N. $65^{\circ}$ W., N. $15^{\circ}$ W., N. $10^{\circ}$ E., and N. $85^{\circ}$ W., respectively.

The N. $65^{\circ} \mathrm{W}$. joints dip about $70^{\circ} \mathrm{S}$. and generally are closely spaced. The intensity of silicification and of brecciation can be correlated with the degree of development of these joints. Apparently the brecciation that gouided the silicifying fluids is mainly the small-scale expression of the stresses that produced the $\mathrm{N} .65^{\circ} \mathrm{W}$. joints. 
The N. $15^{\circ} \mathrm{W}$. and the N. $10^{\circ} \mathrm{E}$. joints dip very steeply east or west, and the $\mathrm{N} .85^{\circ} \mathrm{W}$. joints dip very steeply north or south. The joints are wide-spaced.

The quartz diorite is cut by many veinlets of gray or bluish glassy quartz, usually less than 1 inch thick and rarely more than 3 inches thick. Many veinlets contain a little feldspar, and a few contain as much as 20 percent of feldspar. In most places these veinlets are quantitatively insignificant, but locally they are abundant and in the area designated on plate 8 as "cut by many quartz veinlets" they form a reticulating network, which comprises from 10 to 50 percent of the rock volume. Most of the veinlets occupy steeply dipping N. $65^{\circ} \mathrm{W}$. joints; many are in the steeply dipping N. $15^{\circ} \mathrm{W}$. and N. $85^{\circ} \mathrm{W}$. joints, but relatively few are in joints of the $\mathrm{N} .10^{\circ} \mathrm{E}$. and subordinate joint sets.

The walls of individual veinlets are irregular and are not consistently parallel. The veinlets probably do not represent the simple filling of open fractures, but rather the complete or near-complete replacement of quartz diorite by solutions moving along and working outward from openings only a fraction as wide as the ultimate veinlets. Although the veinlets are most abundant in greatly silicified parts of the quartz diorite, they are locally. abundant in pseudoporphyritic and even in slightly silicified parts; veinlets in little-altered rocks commonly have sharp boundaries.

The quartz diorite is cut by many small dikes, not shown on the maps. Most of the dikes are quartz diorite aplite, but some are enstatite basalt, and a few are hornblende andesite. All the dikes occupy steeply dipping, northward-trending joints. Wherever intersections between dikes and veinlets were observed, the dikes cut and are younger than the veinlets.

\section{MOLYBDENITE DEPOSITS}

\section{MINERALOGY AND DISTRIBUTION}

Molybdenite $\left(\mathrm{MoS}_{2}\right)$ has been observed at many places in the mapped area. ${ }^{21}$ It commonly occurs along the margins of quartz veinlets in silicified quartz diorite and in fractures cutting the veinlets. In a few places molybdenite coats joints containing no vein quartz. Although characteristically in small, paper-thin patches, the mineral locally forms sheets as much as one-fourth inch thick. Rarely it is

\footnotetext{
21 A mineral deposit with "zinc predominating" is shown on plate 2 of the previously noted report by Buddington and Chapin at approximately the location of the main molybdenite deposits, which are not known to contain any zinc minerals. The "zinc predominating" symbol was probably intended to indicate a prospect on a sphalerite-bearing quartz vein near the head of the south arm of Port San Antonio, about 9,000 feet west of the main molybdenite deposits. (See pl. 7.)
} 
disseminated in flakes in the quartz diorite. Molybdenite is most abuindant in the most intensely silicified parts of the quartz diorite, but it also is present in some of the least silicified parts. : A few quartz veinlets that cut the sedimentary rocks near the intrusive contact carry a little molybdenite. In addition to the exposures of molybdenite-bearing rock seen by the writer (see pls. 7 and 8), molybdenite is reported to occur on the west coast of. Baker Island near the northwest boundary of the quartz diorite mass.

Other sulfide minerals associated with molybdenite include small amounts of pyrite, arsenopyrite, and pyrrhotite (?). These minerals are generally in single grains or small aggregates scattered along fractures in quartz veinlets or in unveined quartz diorite. Locally, they replace biotite, hornblende, and chlorite in quartz diorite. The iron-sulfide minerals are rarely in contact with molybdenite; where contacts have been seen, molybdenite cuts and coats all other sulfide minerals.

\section{GRADE AND TONNAGE}

The greatest concentration of molybdenite is within the "area cut by many quartz veinlets." (See pl. 8.) There molybdenite is exposed in relative abundance for about 700 feet along the beach and in most of the outcrops 400 to 600 feet back of the shore, with an exposed vertical range of about 200 feet. Exposures are practically àbsent in this vicinity between 200 and 500 feet altitude; the molybdenite concentration, as well as the quartz veinlet zone, may continue farther inland than shown on plate 8. Inspection of outcrops and of diamonddrill cores suggests that the average molybdenite content of the rocks within the "area cut by many quartz veinlets" from the surface to a depth of about 150 feet below sea level is less than 0.1 percent by weight, and probably is less than 0.05 percent. This estimate of grade is in general agreement with the results: of analyses made for the Kennecott Copper Corp.

Because of the extremely low grade it is not worth while to make precise tonnage estimates. It is evident that the volume of rock considered in the preceding estimate of grade comprises several millions of tons.

The quartz veinlets are reported to carry small amounts of gold. The gold content has not been investigated by the Geological Survey.

Further development of the molybdenite deposits on Baker Island does not appear warranted at present. 


\section{MOLYBDENITE IN GROUNDHOG BASIN, WRANGELL DISTRICT}

\section{By H. R. GaULT}

Groundhog Basin is on the mainland of southeastern Alaska about 13 miles east of Wrangell (see fig. 1 ) and about $91 / 2$ miles by trail from tidewater.

During an investigation of the zinc deposits of Groundhog Basin, made in the summer of $1942,{ }^{22}$ a small molybdenite deposit was found about 1,500 feet $\mathrm{N} .30^{\circ} \mathrm{E}$. from the zinc deposits. Presumably the molybdenite deposit is the one briefly referred to by Smith. ${ }^{23}$ Buddington ${ }^{24}$ describes the geology of the Wrangell district and Gault ${ }^{25}$ the geology of Groundhog Basin.

A large sill of granite crops out along the southwestern slope of the mountain on the northeast side of the South Fork of Porterfield Creek, which drains Groundhog Basin. In many places the contact of the sill with the older gneisses and schists that it intrudes is covered or inaccessible. The sill strikes northwestward parallel to the cleavage and bedding of the gneisses and schists and may continue for several miles across the valley of Porterfield Creek. Its south end is northeast of, and above, the north end of the outcrop of the principal zinc deposits. At its south end it terminates abruptly except for a few apophyses, which continue southeasterly as sills. The sill is at least 1,000 feet wide.

Molybdenite is distributed through an observed vertical range of about 1,000 feet. The boundaries of the deposit were not mapped, but the main molybdenite-bearing part of the sill is at least 100 feet long horizontally, lies between the altitudes of 2,400 feet and 2,600 feet, and is about 300 feet north of the south end of the sill. Fractures in the granite have a moderately regular pattern and are 4 inches to 8 inches apart.

Molybdenite is irregularly distributed as coatings on the fracture surfaces and in quartz veinlets that fill some fractures. No other sulfide minerals were seen with the molybdenite.

${ }^{22}$ Gault, H. R., Zinc deposits of Groundhog Basin, Wrangell district, southeastern Alaska : U. S. Geol. Survey mimeographed report, March 1944.

${ }^{23}$ Smith, P. S., Mineral industry of Alaska in 1930 : U. S. Geol. Survey Bull. 836-A, p. 8, 1933.

${ }^{24}$ Buddington, A. F., Mineral deposits of the Wrangell district, southeastern Alaska: U. S. Geol. Survey Bull. 739-B, pp. 51-75, 1923.

${ }^{25}$ Gault, H. R., Idem. 
Some loose pieces of gneiss and schist below the sill are cut by fractures coated with molybdenite and contain molybdenite-bearing quartz veinlets in fractures and along bedding planes, indicating that the molybdenite mineralization spreads outward slightly beyond the limits of the sill.

No samples of the molybdenite-bearing material have been analyzed by the Geological Survey. It is estimated, by comparison with other molybdenite deposits in southeastern Alaska that have been sampled, that the grade of the material is less than 0.05 percent of molybdenum. 